\title{
Information and communication technology (ICT) applied to quality control to secure performance and compliance in project lifespan
}

\author{
Jeferson Spiering Böes ${ }^{1} \cdot$ Jeferson Ost Patzlaff $^{1}$
}

Received: 18 May 2016/ Accepted: 2 November 2016/Published online: 17 November 2016

(C) Springer International Publishing Switzerland 2016

\begin{abstract}
The validity of the NBR 15575: 2013 has been promoting changes in the construction industry involving the entire production chain, especially regarding the design process, either through steps such as the choice of components and construction systems or in the pursuit of certification construction systems and products, by manufacturers, so that their inputs and components applicable to residential buildings meet the said standard. However, the construction phase also plays a key role in ensuring that the requirements in the project are met. Faced with this context, since the implementation of a Quality Control, you can monitor and manage the enforcement proceedings, seeking and ensuring that these constructive systems to run properly, attesting to the quality of the enterprise as a whole. In this sense, this study points to the use of Information and Communication Technology (ICT) in Quality Control, through the use of current technologies in order to meet compliance with the established requirements and ensure the VUP (Project Lifespan) of edification. Conclusively, the quality control applied during the implementation phase improves the works of production levels with the highest degree of quality, thereby increasing its Lifespan and generating the expected durability.
\end{abstract}

Keywords Building · Quality · Lifespan · Durability · Performance $\cdot$ Execution · Design

Jeferson Spiering Böes

boes.jeferson@gmail.com

Jeferson Ost Patzlaff

jefersonop@unisinos.br

1 Universidade do Vale do Rio dos Sinos-UNISINOS, São Leopoldo, Brazil

\section{Introduction}

The entire construction industry production chain changed with the validity of ABNT NBR 15575:2013-Residential Buildings-Performance. This new standard altered the concepts of production and building, starting with residential buildings. Performance guidelines aim at complying with users' demands. The standard ABNT NBR 15575:2013 refers to the systems that take part in residential buildings, regardless of the constructive systems and the materials used. This standard focus on the demands of users regarding use behavior, without any indication to the constructive systems used [1]. This change alters the relation between the construction company and the client when it comes to expenditure. It is necessary to change the concept of project and building in order to comply with the new requirements.

The execution step also has a key role in complying with the requirements set in the project because it assures the compliance with the expected requirements in all constructive systems. The challenge in complying with the established requirements in projects, such as securing the Project Lifespan (VUP), is the effective control of all activities carried out during construction, checking the quality and the correct execution from a technical perspective. Thus, it is necessary to develop tools to monitor and manage the constructive process, aiming at securing total compliance with these requirements in all construction phases. Quality Control is one way to ensure the compliance and monitor the project execution, certifying the quality as a whole.

According to Righi [2], quality control was implemented to avoid offering the customer defective products. This statement supports ABNT NBR 15575:2013 because quality control becomes a tool with high application 
potential in construction to secure the compliance with the standard, since defective products do not comply with the requirements established and the VUP of a building.

In order to meet the quality in construction and, consequently, achieve total customer satisfaction and be compliant with the requirements established by NBR 15575:2013, companies in the industry have adopted Quality Management Systems, specially ISO 9001 and PBQP-H, both very widespread and solid in the industry. Nonetheless, there are questions concerning the current methodology of data capture and analysis time associated with services rendered in construction. Information and Communication Technology (ICT) is an alternative option, in addition to the current management systems, in order to address these issues.

The latest literature shows a trend in using ICT in construction. Studies carried out by Kim et al. [3], Chen and Namara [4], Leão [5], Nakagawa [6] and Izquierdo [7] about the use of ICT through mobile devices have determined that the monitoring of information in real time has enabled better decision making processes, better problem identification and faster troubleshooting.

Bearing this in mind, we used Information and Communication Technology (ICT) to implement a Quality Control system in real time to monitor and manage executive processes in a construction site in order to control and secure the compliance with the established requirements in the project as well as the VUP. The study was carried out in a construction site in a Logistics Complex, characterized by flexible constructive systems, tight deadlines for completion and high performance level required of its systems.

The following study narrows its analysis to the quality aspects regarding the checklist of services made through the Service Checklist Forms (FVS) and the analysis of this information. Quality control was applied to five selective services: continuous flight auger, prefabricated pillars, concrete floor, Tilt-up, blocks and grade beams for foundation.

\section{Bibliography review}

The performance and durability of the project reflect the quality in building construction industry in which the condition of related services becomes an essential aspect in achieving the projects' quality [8]. Bolina et al. [9] state that the concepts of performance, durability and lifespan are correlated. They state that, according to ABNT NBR 15575 , durability is "the capacity of a building and its system to perform its functions during a period of time and under specific conditions of usage and maintenance." By pointing out that the systems should perform its functions, the standard refers to the behavior of a building or system during its use, which, in other words, is the definition of performance itself according to this standard. In the standard, durability is defined as occurring during a period of time, thus introducing the concept of lifespan as a period in which a building and/or its systems perform the activities for which they were built considering its periodicity and proper execution of maintenance processes.

The word quality may be used according to the features of a product, in which case they meet the client's needs, thus securing the customer satisfaction through that and also through the absence of failure [10]. Hirschfeld [11] states that quality in building construction must be seen broadly, focusing on the various steps of production process and usage, divided in: planning, project, manufacturing materials and components, building execution and usage, operation and maintenance. Hence, quality begins by determining the user's needs, as well as covering the steps of the process in which many products and services are gathered in different levels of quality, leading to a final product that must meet the user's initial needs, identified in the beginning of the process. In recent decades, the construction industry has tried to improve product and service quality standards, focusing its efforts in providing reliability, compliance, durability and, mainly, in meeting the client's needs [12].

Quality control is directly associated to the final quality of the construction and, consequently, is also associated to the compliance of the established requirements, besides securing VUP. For Marosszeky et al. [13], quality control and the execution of construction tasks must be performed simultaneously as to identify quality issues and act in a way to limit its occurrence. Picchi and Agopyan [14] state that quality control must cover all of the following stages of construction:

1. Prototype unit analysis (full scale early assessment of products and specified processes);

2. Pre-assembly control (quality control of mould, frames, hydraulic sets and other pre-assembly products before being sent to construction site);

3. Subcontractor qualification (skill evaluation prior to service contract);

4. Planning and equipment control (to secure its allocation as per planning);

5. Quality control of finished product and control maintenance until final delivery to client.

According to Picchi and Agopyan [14], quality control in building construction must be a standardized monitoring constituted by goals, and evaluating priority aspects according to the standards established in regulations. It also must have acceptance criteria and indicate the level of tolerance allowed. 
The construction industry works on an intense pace of information flow that must be sent back and forth during the project lifespan [4], and it is essential for contractors nowadays. To handle effectively the information flow between stakeholders along the whole process is one of the key factors in securing the project's success [15]. Failure in doing so may result in pathological problems and low quality [16]. The lack of information in real time is also a characteristic of the building construction industry. This absence generates obstacles and reduces the capacity of managers to follow performance indexes, which unables them to detect or control variability and uncertainty associated to construction tasks [17].

Information and Communication Technology (ICT) captures, stores, renders and shares information electronically. Building construction has not yet fully adopted these technologies in its processes [15]. Nonetheless, Moraes et al. [18], determined that this scenario has changed in the last years and building construction has been integrating ICT in its processes. According to Kim et al. [3], it is a challenge for engineers to collect information from the entire construction site in real time. To overcome this scenario, it is necessary to employ Information and Communication Technology. Leão [5] supports Kim et al. [3] and points out the use of mobile devices in construction sites is as an alternative to effectively collect and manage information during a construction. Using mobile devices in building construction has been one of the main research topics and case studies in the Information Technology in Construction area (ITC) [4].

To have an effective exchange of information amongst participants is not an easy task because construction sites with large areas, adverse weather conditions and resources scattered around the site present a challenge to engineers and managers who wish to extract information from the site where the action is happening and send it to the office [19]. Using Information and Communication Technology for quality control in construction sites is breaking new ground because it allows the use of a software as a beneficial and potential alternative [20].

Moreover, Bowden et al. [21] highlight the benefits of using mobile devices in construction sites:

1. Work quality;

2. Non-compliants are detected early in the process, which leads to an effective intervention regarding costs;

3. Failures are immediately communicated to contractors, improving the corrective action process.

\section{Case study}

\subsection{Software used}

The software used for implementing quality control is oriented towards the building construction mobility. It was designed to collect information in real time that both work as a foundation for strategic decision making processes, and quality improvement, cost reduction, environment sustainability and effective decision making. It works in two platforms: Web and mobile. The Web platform is used for registering forms, and receiving, centralizing and rendering all information gathered from the site. This platform allows users to manage modules in real time and monitor construction indexes. The mobile platform is used for collecting information from the site. With this platform, the user can perform inspections, register $\mathrm{NC}$ and send forms to the $\mathrm{Web}$ platform. Workers in the construction site may use this software as an app on smartphones and tablets which they can use to track quality, productivity and workforce in real time. Its system is enabled for use online and offline, thus being useful even in sites with no Internet access.

\subsection{Hardware used}

For this case study, two hardware platforms were used: laptop and tablet.

Laptop Samsung RV420-2310 M, with the following settings: Intel Core i3 processor, 4 GB RAM, speed of $2.1 \mathrm{GHz}$ and $500 \mathrm{~GB}$ of hard drive.

Tablet Samsung Galaxy Tab 4, with the following settings: OS Android 4.0, speed $1.2 \mathrm{GHz}$, memory of $16 \mathrm{~GB}$, Wi-fi and 3G.

\subsection{Implementation}

Due to the tight deadline and the necessity of getting more quality control of services provided, in order to secure compliance to established requirements in the project, as the VUP, five tasks were set to implement the quality control. The services were implemented during the case study and covered main tasks performed in the construction, such as the laying of foundations of the kind continuous flight auger, pile caps, prefabricated pillars, floor and Tilt-up execution. Table 1 shows Service Checklist Spreadsheets (FVS) related to the tasks observed during this case study.

The FVS the company has in its Construction Quality Plan in paper were sent to the Web platform of the software, thus making it possible to maintain the same inspection standard that the company already used. Besides that, it was added to each FVS the required inspections 
Table 1 Service checklist spreadsheet list. Source: Böes [20]

\begin{tabular}{ll}
\hline $\begin{array}{l}\text { Service checklist } \\
\text { spreadsheets (FVS) }\end{array}$ & Description \\
\hline FVS-003 & $\begin{array}{l}\text { Deep foundations } \\
\text { Pile cap }\end{array}$ \\
FVS-004 & Concrete floor (sub-base) \\
FVS-006B & Concrete floor (forms) \\
FVS-006C & Concrete floor (concreting) \\
FVS-006D & Concrete floor (finishing) \\
FVS-006E & Concrete floor (expansion joints) \\
FVS-030A & Tilt-up execution (forms) \\
FVS-030B & Tilt-up execution (framework) \\
FVS-030C & Tilt-up execution (concreting) \\
FVS-031 & Prefabricated pillars (receipt) \\
FVS-034 & Prefabricated pillars (mounting) \\
\hline
\end{tabular}

regarding the verification of requirement compliance established in the project, such as the VUP.

The data collection step lasted for three months and was performed upon conclusion of each service with FVS quality inspections made on the tablet. It was not necessary to access the Internet while performing the FVS, thus reinforcing the platform's capacity to work entirely offline. The quality control was performed by the company's quality team. The data was sent automatically from the site to the Web platform as soon as the inspections were performed, allowing the person in charge for quality management to track the performance of services rendered in real time. Figures 1 and 2 show the format of the inspection via mobile platform.

The FVS used in quality control had predefined answers associated with the item inspected set when registering it in the web platform. It shows items that must be verified in each element, the methodology for checking them, tolerance or acceptance criteria for deviation and a field to enter notes about the inspection. All of these specifications were created according to the performance requirements established in the project for securing the VUP.

The FVS was designed for an eventual non-acceptance of an inspected item, upon which a Non-Compliance (NC) notification would be automatically generated. In this case, the mobile platform opens a new window in which the inspector may complete the NC in loco, allowing him to report the event precisely and with as much information as possible without any loss during the process. Besides filling out the NC with the root causes of the event and the description of the problem, the inspector can attach photos to illustrate the issue found. Figure 3 presents this application. Upon completing the NC and the FVS, the form is sent to the web platform. This informs managers automatically about the occurrence of a deviation in the specified standard. Other parties responsible for the service are also notified in order to allow an effective corrective response.

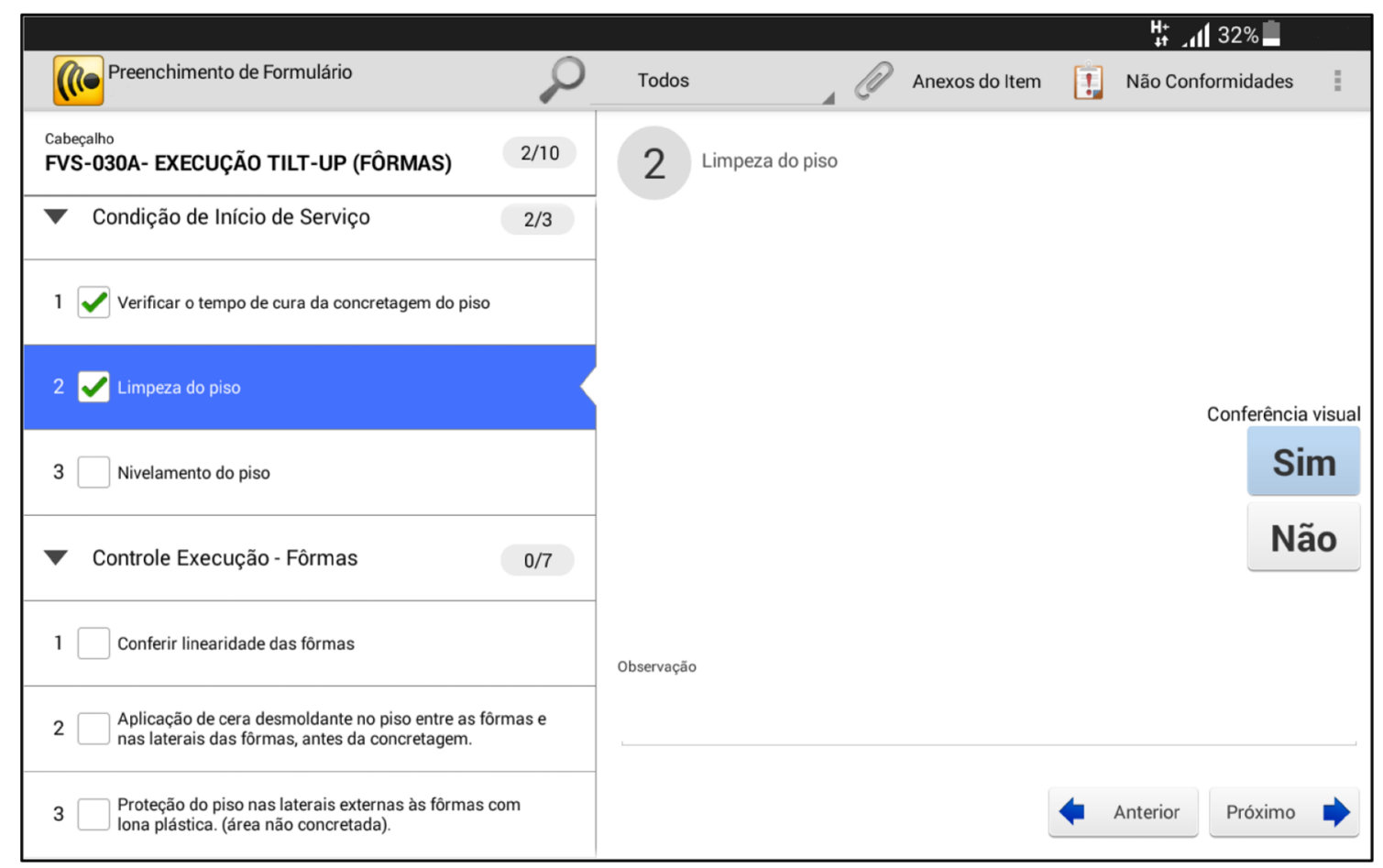

Fig. 1 Quality control enforcement-tilt-up execution. Source: Böes [20] (color figure online) 


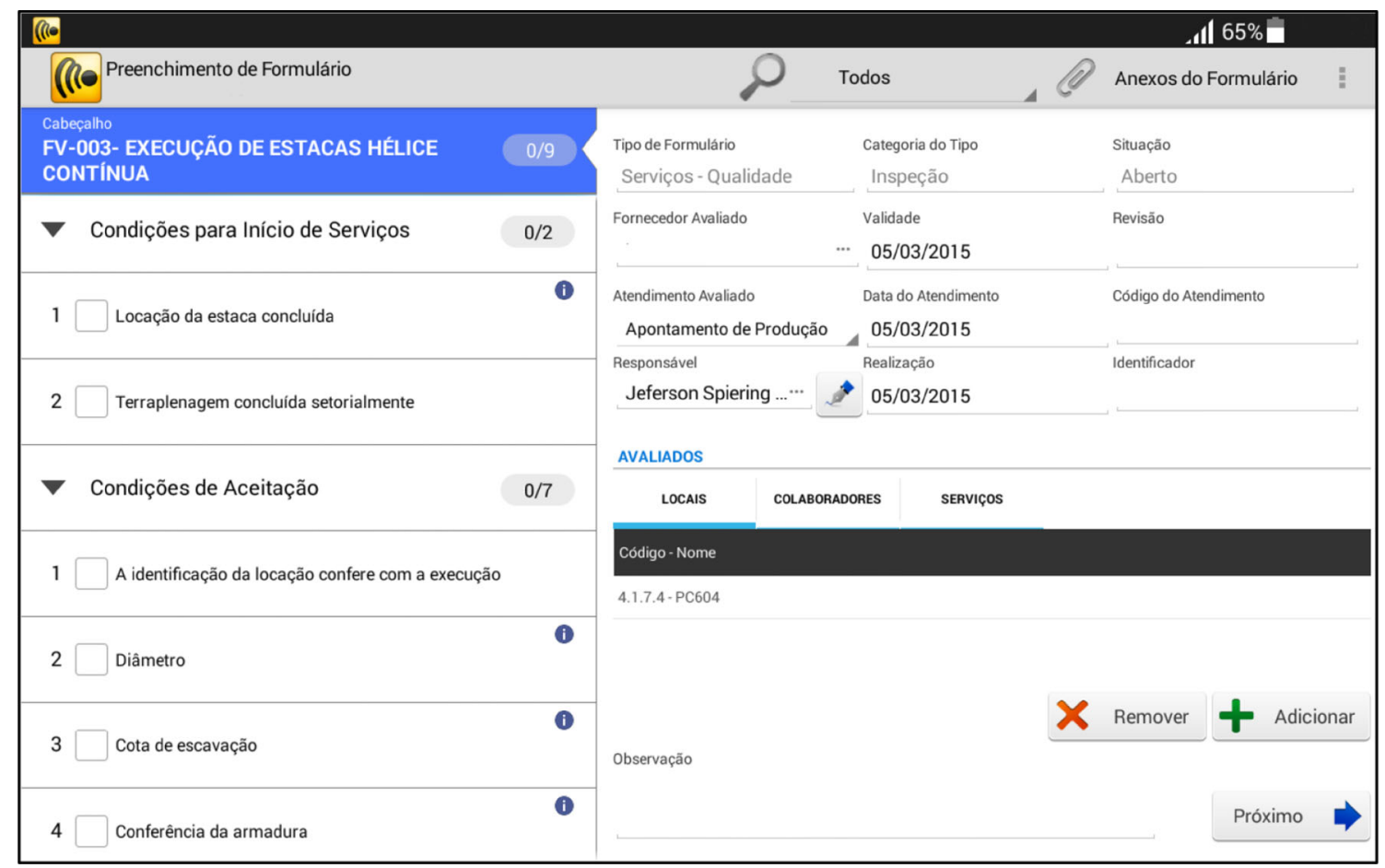

Fig. 2 Quality control enforcement—continuous flight auger execution. Source: Böes [20] (color figure online)

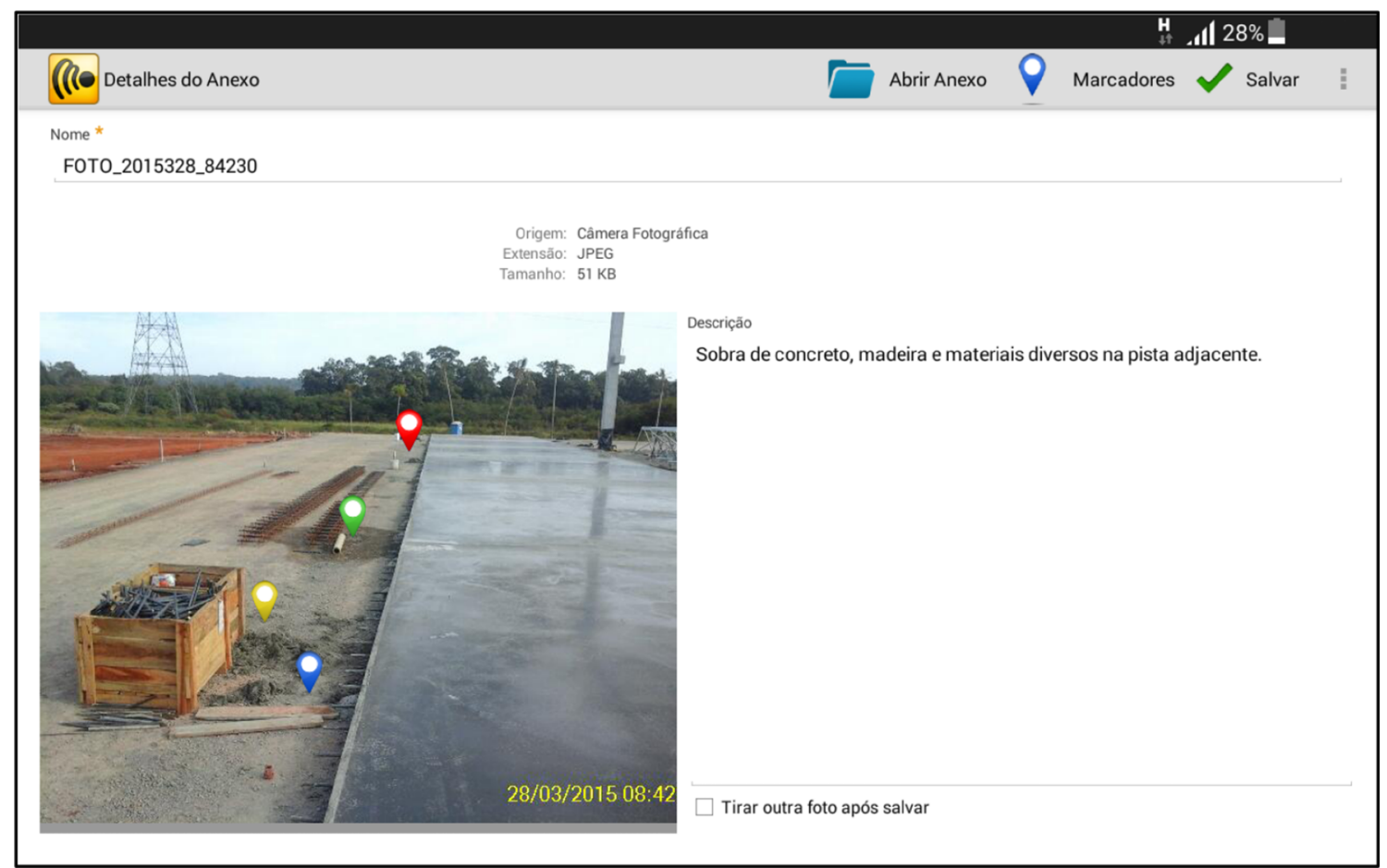

Fig. 3 Photo of NC. Source: Böes [20] (color figure online)

The NC is registered in the system and remains in the history of the deviation. From this moment, the problem is monitored until its solution, which is also evaluated. This method allows recording the person responsible for the service execution, as well as the material and equipment used. 


\section{Results}

During this case study, 237 elements were inspected, including continuous flight augers, pile caps, prefabricated pillars, concrete floors and Tilt-up, producing a total of 2237 items inspected, 247 FVS applied as shown in Fig. 4.

The web platform allowed monitoring the construction quality performance through indexes in real time, which the quality and management team could access daily. The monitoring was performed through a tool of the Web platform called Quality Panel-Forms. This tool is a dashboard, shown in Fig. 5, which in a single layout is possible to monitor and analyze the quality performance of the services rendered, besides measuring the compliance of the construction and determining which services present deviations. The company in this case study determined the following ranking for compliance: Poor 0-90\%, Medium 90.1-95\%, and Good 95.1-100\%. The Quality Panel was updated as each new form was sent from the site through the mobile platform.

Another tool provided by the Web platform was Quality Panel-Non-Compliances. In this dashboard, NCs
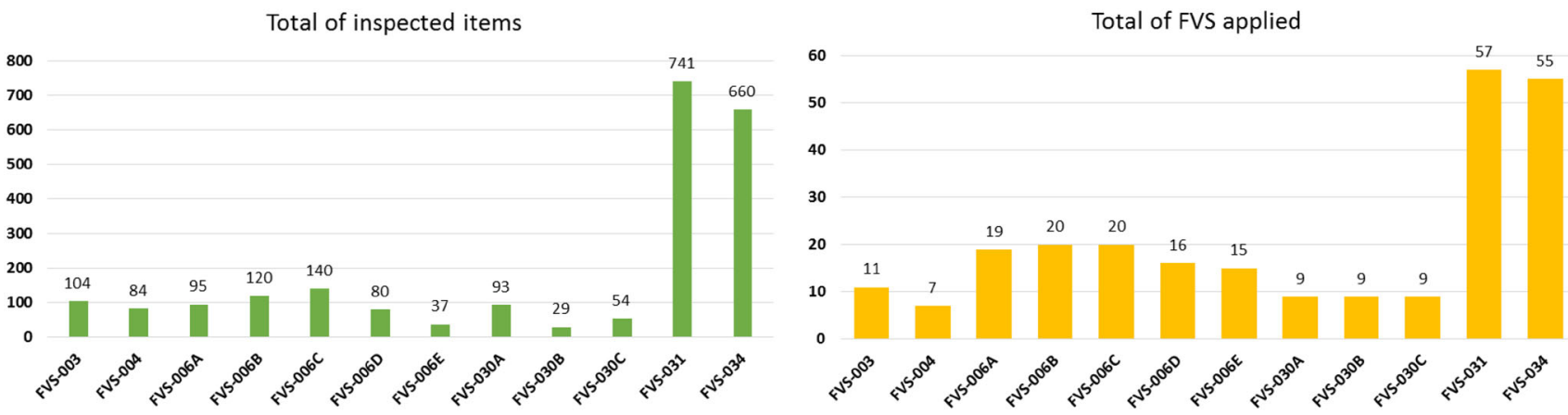

Fig. 4 Total of inspected items. Source: Böes [20] (color figure online)

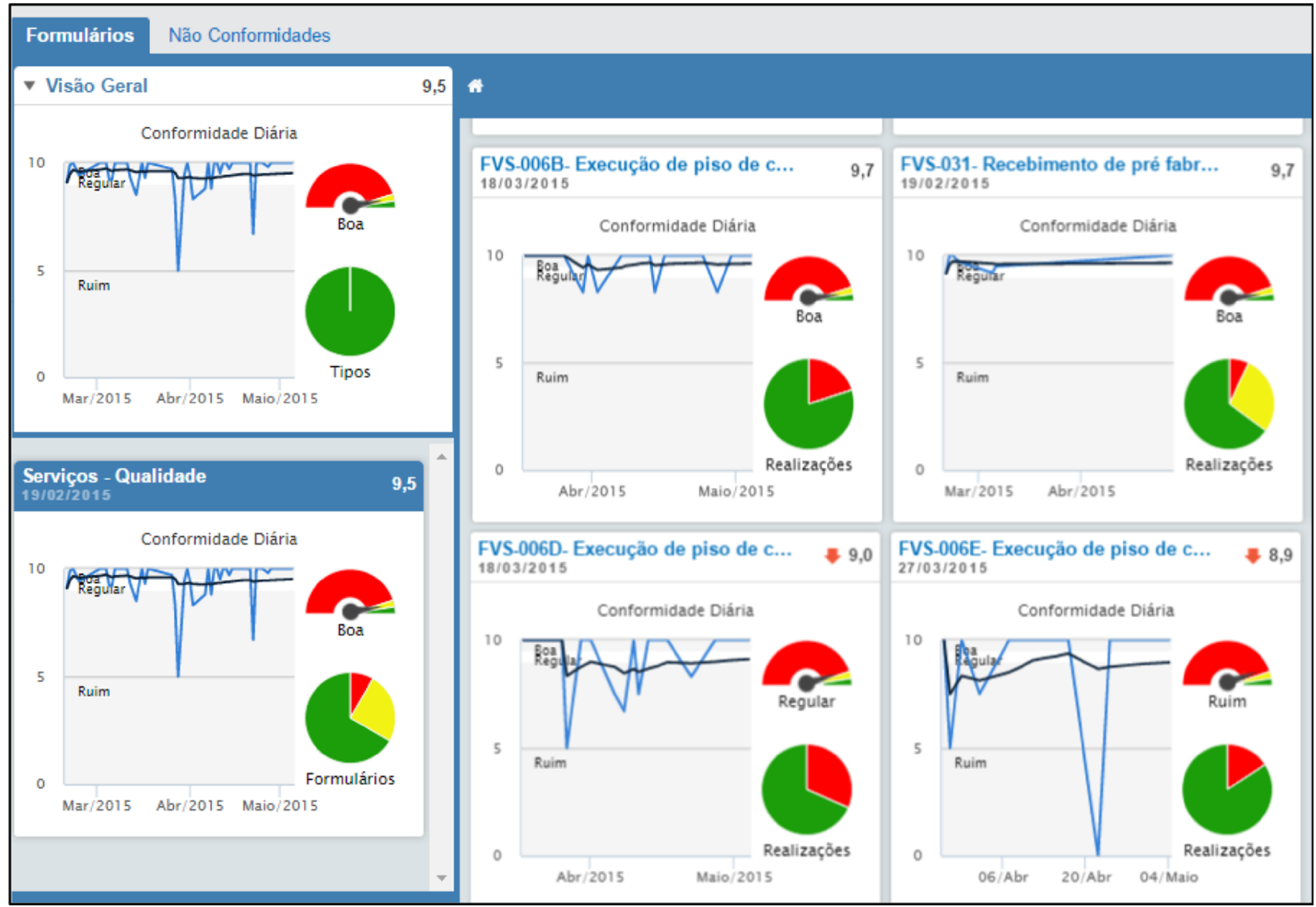

Fig. 5 Quality panel—forms. Source: Böes [20] (color figure online) 


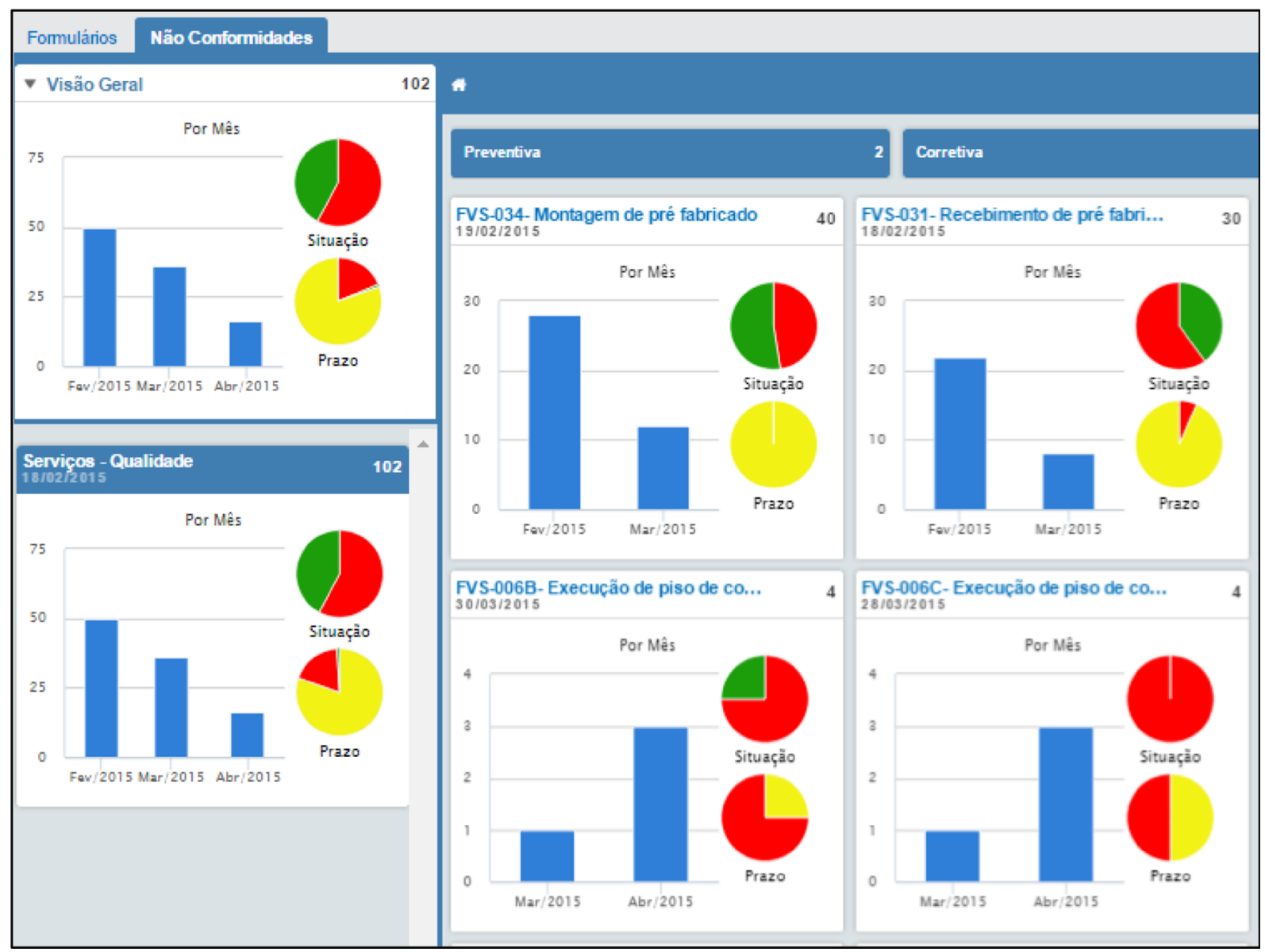

Fig. 6 Quality panel—non-compliances. Source: Böes [20] (color figure online)

Fig. 7 Non-compliances per form. Source: Böes [20] (color figure online)
Non-Compliances per form

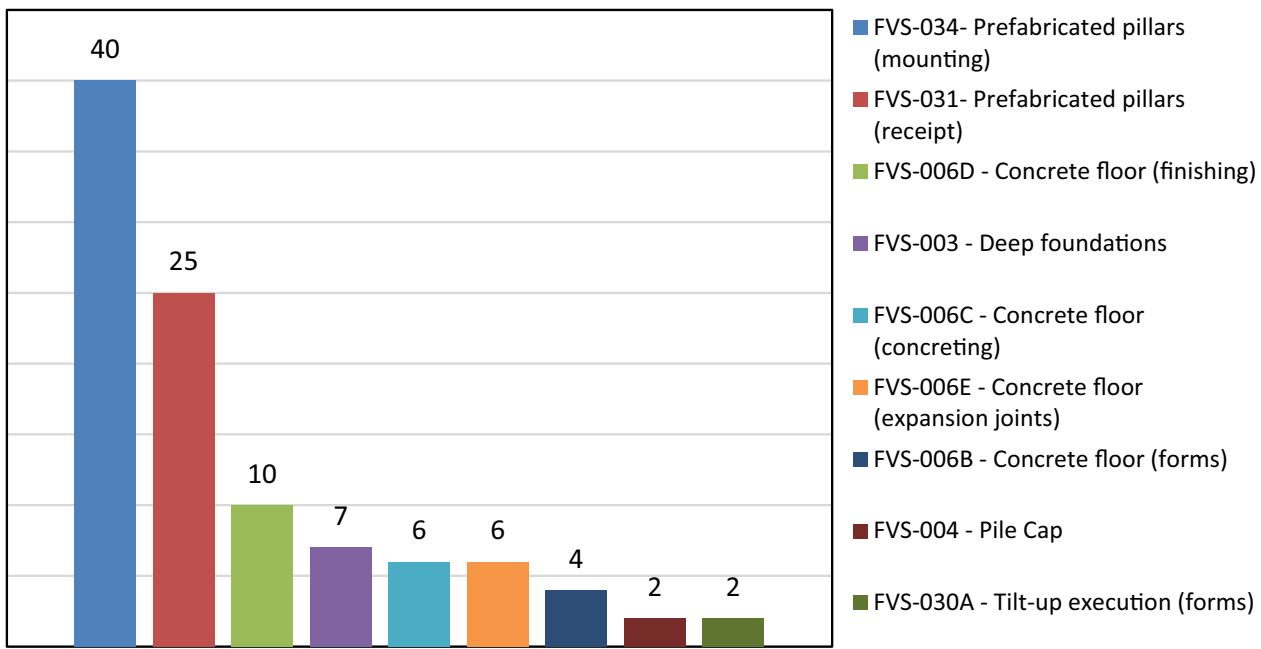

generated during the construction were shown, separated by completed forms. This tool allowed deviation management, the monitoring of $\mathrm{NCs}$ regarding their correction deadline, correction effectiveness and root cause. The dashboard was very important because the whole process of deviation recovery was done through it, securing the resolution of problems found in the construction. Figure 6 shows this dashboard.

NCs generated by completed forms were also taken into account when main activities that registered problems 
Fig. 8 Non-compliances per contractor. Source: Böes [20] (color figure online)

\section{Non-Compliances per Subcontractor}

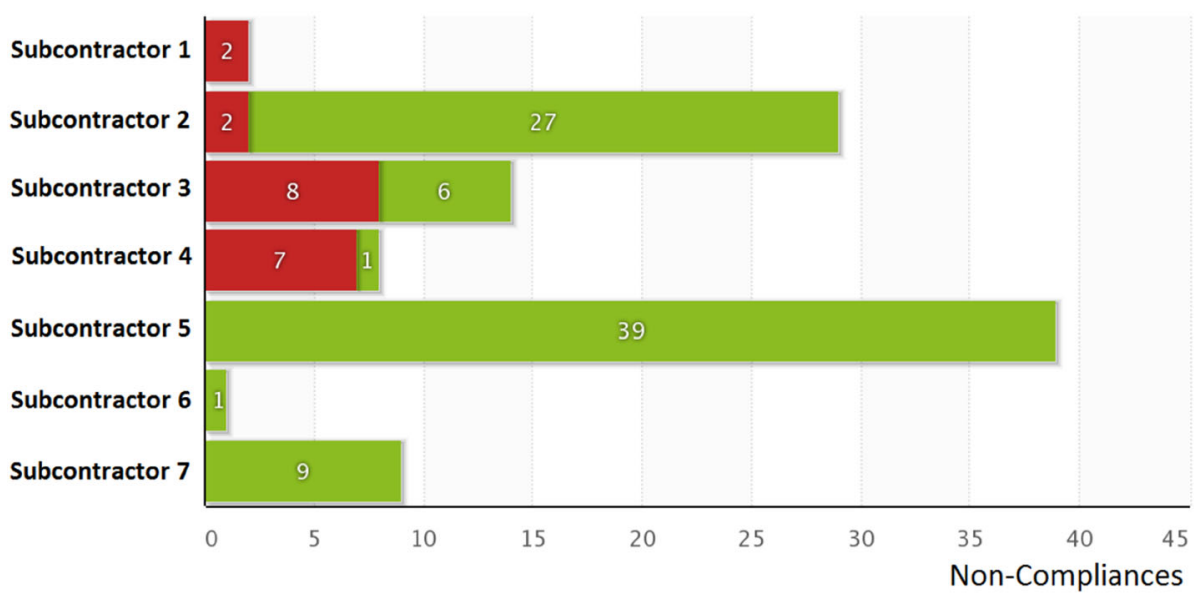

\section{Schedule Nearing the expiration date Expired}

Fig. 9 Traceability of noncompliances-concrete floor Source: Böes [20] (color figure online)

\section{Traceability of Non-Compliances -Concrete floor}

Concrete floor 1
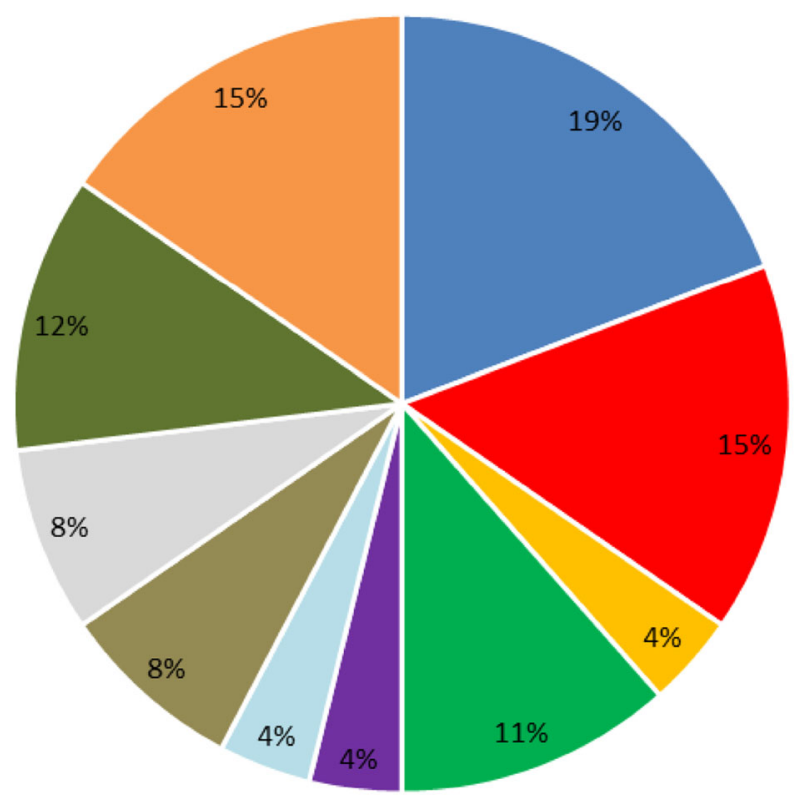

- Concrete floor 2

Concrete floor 3

- Concrete floor 5

- Concrete floor 7

Concrete floor 9

Concrete floor 11

Concrete floor 12

- Concrete floor 14

Concrete floor 15 during their execution were observed. This information was utterly important because it served as a basis for quality analysis of the services rendered in the construction site. A good example is FVS-034-Prefabricated assembly in which, after determining a significant volume of FVS, it was established the necessity for discovering the root cause of the NCs and training the responsible team for providing that specific service in order to reduce deviations as well as recovering from deviations already detected. In this sense, it was determined a high volume of NCs in FVS-031Prefabricated receipt in which NC generated by the software were forwarded to the product supplier. This finding was fundamental for product improvement, which in the second delivered batch presented a significant improvement in quality. Figure 7 presents Non-Compliances per form applied. 
Figure 8 presents NC per contractors, including NC on schedule, expired, or nearing the expiration date. Through this information, it is possible to determine deviations on the contractors' side. This information was presented in meetings which covered indexes and provided trainings to capacitate the workers in order to improve the compliance and, consequently, meet the performance requirements established in the projects as well as securing the VUP. It is possible to determine that after the actions taken based on the information in loco, the contractors had a more proactive behavior in relation to their concern with the quality of the services provided.

Since the implementation of the quality control process through the use of ICT, it is possible to track the NCs found as to generate an analytical evaluation. Figure 9 presents the traceability of the NCs generated on concrete floor. They were divided in concreting lanes as per project. The traceability was essential because it allowed to determine the circumstances that led to the generation of $\mathrm{NC}$ on a given day, such as the lack of equipment or materials, changes in the weather, or human error. The tool also allowed to fully monitor services and elements executed, offering total control over the performance of elements, and in the case of $\mathrm{NC}$, track them and request a corrective action.

\section{Conclusion}

The use of Information and Communication Technology (ICT) in managing quality in the studied construction showed itself to be completely satisfactory and applicable. According to the major parameters, determined during the research, we conclude that the use of this tool for monitoring may be expanded to all services rendered in a construction site and for control management in large scale. The production sector of the project had a high adoption rate in the applicability of ICT through the use of tablets for filling out FVS as it offered effective certification that the services provided met the established requirements, encouraging the constant use of tablets in the construction site.

The use of the software allowed project managers to monitor in real time indexes and follow tasks performed. The dashboards allowed, through its versatile information flow and its direct language and dynamics, understand and provide an overview of the NCs and the coverage of FVSs in the whole construction project. Another benefit gained by the implementation of software was the automatic reporting of FVs and NCs. This automation allowed an effective management and forwarding of diagnosed problems to the team responsible for their solution.
Finally, the use of Information and Communication Technology in quality control of construction projects can secure the compliance to performance requirements established in the project as well as contribute, from the assurance that the project will be carried out in line with the parameters established in the project, to the compliance to the VUP. The quality control performed effectively in loco and the monitoring of Non-Compliances until their resolution are proofs and guarantees that the project meets the requirements.

\section{References}

1. Associação Brasileira de Normas Técnicas (ABNT) (2013) NBR 15575: edificações habitacionais-desempenho. ABNT, Rio de Janeiro

2. Righi MR (2009) Sistema de controle da qualidade e planejamento de curto prazo na construção civil: integração e compartilhamento de informações. 2009. 73 f. Trabalho de Diplomação (Graduação em Engenharia Civil)—Departamento de Engenharia Civil. Universidade Federal do Rio Grande do Sul, Porto Alegre

3. Kim C et al (2013) On-site construction management using mobile computing technology. Autom Constr 35:415-423

4. Chen Y, Kamara JM (2011) A framework for using mobile computing for information management on construction sites. Autom Constr 20(7):776-788

5. Leão CF (2014) Proposta de modelo para controle integrado da produção e da qualidade utilizando tecnologia de informação. 2014. Dissertação (Mestrado em Engenharia)—Programa de PósGraduação em Engenharia Civil, UFRGS, Porto Alegre

6. Nakagawa Y (2006) Real time performance information system. In: Annual conference of the international group of lean construction, 14, Santiago, 2006. Anais, Santiago

7. Izquierdo EMÁ (2013) Developing a construction management software for mobile devices. 2013. Proyecto final (Grado) Grado em Ingeniería de la Edificación, Escola Politècnica Superior d'Edificació de Barcelona-Universitat Politècnica de Catalunya, Barcelona

8. Braz, de Oliveira AJ (1999) Da qualidade dos serviços da construção: contribuição para a sua melhoria em Portugal. Lisboa: Ministério do Equipamento Social. Laboratório Nacional de Engenharia Civil

9. Bolina F, Patzlaff JO, Fernandes B (2015) Tutikian/Análise do grau de contaminação do terreno para projeto estrutural de fundações: estudo de caso. In: Anais do XIII Congresso LatinoAmericano de Patologia da Construção. Lisboa

10. Juran JM, Gryna FM (1991) Controle da qualidade, vol. 1: Conceitos, políticas e filosofia da qualidade. Makron McGrawHill, São Paulo

11. Hirschfeld H (1996) A construção civil e a qualidade: informações e recomendações para engenheiros, arquitetos, gerenciadores, empresários e colaboradores que atuam na construção civil. Atlas, São Paulo

12. Costa DB et al (2005) Sistema de indicadores para benchmarking na construção civil: manual de utilização. UFGRS/PPGEC/ NORIE, Porto Alegre

13. Marosszeky M et al (2002) Quality management tools for lean production: moving from enforcement to empowerment. In: Annual Conference of the International Group for Lean Construction, 10, 2002, Gramado. Proceedings. Gramado: IGLC 
14. Picchi FA, Agopyan V (1993) Sistemas da qualidade na construção de edifícios. EPUSP, Boletim Técnico da Escola Politécnica da Universidade de São Paulo, São Paulo

15. Nascimento LA, Santos ET (2008) A indústria da construção na era da informação. Ambiente Construído 11:69-81

16. Tzortzopoulos P (1999) Contribuições para o desenvolvimento de um modelo do processo de projeto de edificações em empresas construtoras incorporadores de pequeno porte. Dissertação (Mestrado em Engenharia)-Programa de Pós-Graduação em Engenharia Civil, UFRGS, Porto Alegre

17. Howell G, Koskela L (2000) Reforming project management: the role of lean construction. In: Annual Conference of The International Group of Lean Construction, 8, Brighton, 2000. Anais, Brighton
18. Moraes RMM, Guerrini F, Serra SMB (2006) Aplicação de tecnologia de informação no setor da construção civil. In: Simpósio de Engenharia de Produção, 12, 2006, Bauru. Anais, Bauru

19. Kim C, Lim H, Kim H (2011) Mobile computing platform for construction site management. In: Proceedings of 28th International Symposium on Automation and Robotics in Construction. Seoul, Korea

20. Böes JS (2015) Tecnologia da Informação e Comunicação (TIC) aplicada ao sistema de qualidade de obras: estudo de caso. Trabalho de Conclusão de Curso (Engenharia Civil)—Universidade do Vale do Rio dos Sinos, São Leopoldo

21. Bowden $\mathrm{S}$ et al (2005) Making the case for mobile IT in construction. Comput Civil Eng:1-12. doi:10.1061/40794(179)46 